\title{
PENYELESAIAN KONFLIK PEWARISAN AKIBAT HIBAH BERDASARKAN HUKUM PROGRESIF
}

\author{
Kajian Putusan Nomor 95/PDT.G/2008/PN.BKS \\ THE CONFLICT RESOLUTION OF THE GRANT OF \\ INHERITANCE IN ACCORDANCE TO PROGRESSIVE LAW
}

\author{
An Analysis of Court Decision Number 95/PDT.G/2008/PN.BKS \\ Poniman \\ Fakultas Hukum Universitas Diponegoro \\ J1. Imam Bardjo No. 1 Semarang 50241 \\ E-mail: jatinegara.restegal@yahoo.com
}

Naskah diterima: 2 Februari 2017; revisi: 20 Maret 2017; disetujui: 29 Maret 2017

\begin{abstract}
ABSTRAK
Putusan Pengadilan Negeri Bekasi Nomor 95/ PDT.G/2008/PN.BKS menolak dan menghukum gugatan penggugat untuk membayar biaya perkara, dan memutuskan bahwa harta pewaris seluruhnya menjadi hak anak luar kawin tidak diakui karena hibah dari pewaris. Dari sisi penegakan hukum positif, hakim mendasarkan putusan hanya pada pembuktian tanpa menelusuri realitas dari akta hibah tersebut yang cacat hukum. Kajian penelitian putusan ini menggunakan teori hukum progresif dalam upaya mencari keadilan, dengan mengkaji permasalahan, serta bagaimana penyelesaian konflik pewarisan akibat hibah berdasarkan hukum progresif. Penelitian ini adalah penelitian socio-legal dengan pendekatan induktif yang berparadigma postpositivisme. Penelitian ini dilakukan secara kualitatif dengan mengutamakan kedalaman data dengan narasumber yang berkompeten di bidangnya. Dari penelitian ini, realita bahwa anak luar kawin tidak diakui dapat menguasai seluruh harta pewaris dengan hanya berdasarkan pada akta keterangan hibah, mestinya tidak terjadi. Hal ini menunjukkan betapa lemahnya peradilan yang hanya menggunakan hukum formalisme semata, sebagai puncak kepastian hukumnya, sehingga tujuan manfaat dan keadilan belum terpenuhi. Pola hukum progresif berfondasi pada progresivitas manusia, bahwa manusia sebenarnya baik, penuh kasih sayang, saling
\end{abstract} tolong menolong, dan empati kepada sesama manusia. Berhukum yang benar adalah berhukum yang bertujuan demi tercapainya keadilan masyarakat.

Kata kunci: hibah, harta warisan, anak luar kawin tidak diakui, hukum progresif.

\section{ABSTRACT}

Bekasi District Court Decision Number 95/PDT.G/2008/ $P N . B K S$ objected the claim and give sanction to the plaintiff to pay court costs, and decided that all the assets of the testator became solely the possession or title of the child out of wedlock of no recognition owing to the grant of the testator. In terms of positive law enforcement, the judges based the ruling solely on proving without probing the legitimacy of the legally flawed grant deed. This analysis employed the theory of progressive laws in an effort to seek justice by studying the problems as well as the conflict settlement of the case of grant-based heir derived from progressive law. This is a socio-legal research study using inductive approach through the perspective of post-positivism. Qualitative research was conducted primarily by collecting references from the experts in the relevant field. From this research, it can be inferred that the granting of ownership to the entire inheritance to the child out of wedlock of no recognition based solely upon a Grant Deed should not have 
occurred. This indicates just how weak the judiciary is, barely imposing a mere formal law as the culmination of its legal certainty resulting in the unfulfilled objectives of law, those of the benefit and equity. The pattern of progressive law is based on the progression of humans that human beings are actually good, compassionate, mutually helpful to each other, and empathetic for their fellow human beings. Indeed the true law is aimed at achieving social justice.

Keywords: grant, inheritance, child out of wedlock of no recognition, progressive law.

\section{PENDAHULUAN}

\section{A. Latar Belakang}

Penyelesaian konflik pewarisan dan hibah menjadi sangat penting diteliti, karena proses di pengadilan masih banyak kendala dalam memperoleh keadilan. Putusan Nomor 95/ PDT.G/2008/PN.BKS, tanggal 2 September 2008 menolak gugatan penggugat (anak dan istri ahli waris sah) dan menghukum penggugat dengan membayar biaya perkara. Kasus pewarisan ini dimenangkan oleh tergugat anak luar kawin tidak diakui secara hukum karena mampu menunjukkan surat keterangan hibah dari pewaris ketika masih hidup.

Posisi kasus, ketika pewaris masih hidup, bersama istri dan anaknya hidup bersama dalam berumah tangga, pewaris dikenal sebagai pengusaha sukses, menangani usaha kontrakan rumah dan toko (ruko) dengan luas lahan kurang lebih $4.500 \mathrm{~m} 2$. Lokasi kontrakan sudah berbentuk layaknya pasar dan terminal angkutan kota (di kota Bekasi mulai tahun 90-an). Suatu hari pewaris bertemu dengan keluarga yang tidak mampu dan memiliki seorang anak/wanita (umur lima tahun) yang perlu pertolongan. Oleh karena ada rasa iba, kasihan, dan demi kemanusiaan, pewaris bermaksud menolong dan membawanya ke rumah untuk disekolahkan. Dengan berjalannya waktu sampai akhirnya setelah dewasa dikawinkan. Anak tersebut adalah anak luar kawin tidak diakui secara sah (menurut peraturan perundangundangan pengangkatan anak).

Ketika pewaris meninggal dunia, seketika itu anak luar kawin langsung mengambil alih seluruh harta (tanah, rumah, dan usaha kontrakan) dan mulai berperilaku tidak senonoh, mendesak agar istri dan anak almarhum pewaris keluar rumah (diusir) karena merasa seluruh harta peninggalan almarhum sudah dimilikinya karena hibah. Dari keadaan demikian, istri dan anak pewaris berkali-kali meminta keadilan kepada kepala desa dan aparat keamanan desa, agar haknya sebagai pewaris sah diberikan. Pihak desa sampai kecamatan berkali-kali juga melakukan mediasi, namun tidak menghasilkan kesepakatan. Kasus dilaporkan ke pihak kepolisian, oleh penyidik dinyatakan tidak cukup bukti (Surat Pemberitahuan Penghentian Penyidikan/SP3). Karena tidak mendapatkan keadilan ahli waris (anak dan istri) melalui pengacaranya menggugat di Pengadilan Negeri Bekasi. Di pengadilan negeri tersebut sampai Mahkamah Agung pun tidak mendapatkan keadilan karena kasus ditolak.

Secara yuridis korban (ahli waris sah/ anak dan istri) dikalahkan dan menderita rugi tidak mendapatkan warisan dari mendiang almarhum suaminya. Secara ekonomi korban tidak mendapatkan hasil/nafkah untuk penghidupannya, karena tempat usaha dikuasai anak luar kawin. Secara sosial budaya, malu dan terjadi ketidakharmonisan rumah tangganya di 
kampung halaman. Secara fisik terjadi konflik, maupun psikis memengaruhi jiwa yang tidak tenang dari perlakuan anak luar kawin yang berbuat tidak senonoh. Setelah tujuh tahun lamanya dengan siasat yang patut dicurigai anak luar kawin ternyata mampu berdalih untuk menunjukkan surat keterangan hibah dari pewaris/ almarhum yang dibuat oleh Pejabat Pembuat Akta Sementara (PPATS/Camat Bekasi).

Surat keterangan hibah secara substansial kurang memenuhi ketentuan penghibahan menurut undang-undang (KUHPerdata tentang Penghibahan), antara lain tanda tangan penghibah diragukan kebenarannya, penerima hibah anak luar kawin tertulis anak luar kawin binti penghibah sebenarnya bukan anak kandung penghibah, pemberian hibah seluruh harta usaha penghibah tanpa kecuali, demikian ini melanggar bagian hak ahli waris yang lain (anak-istri penghibah). Dari latar belakang tersebut di atas peneliti mengangkat kajian dari aspek hukum progresif agar digunakan sebagai kebijakan dalam memperoleh keadilan substansial.

\section{B. Rumusan Masalah}

Dari latar belakang tersebut di atas dirumuskan pokok permasalahan sebagai berikut: bagaimana penyelesaian konflik pewarisan akibat hibah berdasarkan hukum progresif?

\section{Tujuan dan Kegunaan}

Tujuan dan kegunaan dari penelitian ini yaitu: 1) secara teoritis: hasil penelitian ini diharapkan dapat memberikan sumbangan pemikiran atau kemanfaatan bagi penegak hukum (hakim) dalam memutuskan suatu perkara, dengan tidak hanya menggunakan hukum positif semata, namun dengan pertimbangan kemanusiaan dalam memutus perkara konflik pewarisan akibat hibah yang berfondasi dari progresivitas manusia dalam berhukum progresif; dan 2) secara praktis: hasil penelitian ini diharapkan dapat menjadi suatu kebijakan bagi penegak hukum (hakim) dalam memutus perkara konflik pewarisan akibat hibah dengan cara berhukum progresif sebagai kebijakan/pedoman berhukum di pengadilan dalam upaya mencapai nilai-nilai keadilan (searching for justice) sehingga tercapai keadilan substansial.

\section{Tinjauan Pustaka}

Berkaitan dengan ketentuan hukum penghibahan tersebut di atas diatur pada Kitab KUHP Buku ke-3 Bab X bagian ke-1 sampai bagian ke-4 dan Pasal 1666 sampai Pasal 1693 yang dalam ketentuan umumnya dinyatakan sebagai berikut:

"....bahwa penghibahan dapat dilakukan ketika penghibah masih hidup dalam keadaan sehat jasmani dan rohani serta cakap, dan penghibahan dilakukan kepada penerima hibah (yang memenuhi syarat-syarat penerima hibah yang sah), penghibahan dilakukan harus diketahui ahli waris yang lain, tanah, dan bangunan yang akan dihibahkan sudah ada terlebih dahulu sebelum hibah dilakukan/sebelum penghibahan dimulai, penghibahan tidak boleh ditarik kembali jika telah memenuhi syarat-syarat yang ditentukan dalam peraturan perundang-undangan (KUHPerdata) serta penghibahan tidak boleh melebihi hak atas waris yang lain atau tidak boleh melanggar pewarisan...."

Dalam kamus bahasa Indonesia, konflik dimaknai sebagai perselisihan antara satu orang/individu dengan individu yang lain atau antar kelompok yang dapat diselesaikan dengan cara mempertemukan (conciliation)/ memusyawarahkan sehingga tercapai 
kesepakatan. Konflik/sengketa ini biasanya dalam ranah perkara perdata. Dalam penelitian ini konflik dimaknai sebagai suatu perselisihan pewarisan antara ahli waris sah dengan anak luar kawin tidak diakui, akibat hibah berdasarkan hukum progresif yang berujung sampai tuntutan di pengadilan.

Hal yang diperkarakan pada gugatan ini adalah harta peninggalan dari pewaris. Penegakan hukum mestinya melakukan penegakan sesuai dengan ketentuan yang ada mulai dari tingkat penerimaan laporan di pihak kepolisian tentang adanya dugaan pemalsuan surat, sebagaimana dinyatakan pada Pasal 266 ayat (1) KUHP sebagai berikut:

“..... barang siapa menyuruh memasukkan keterangan palsu ke dalam suatu akta otentik mengenai sesuatu hal yang kebenarannya harus dinyatakan oleh akta itu, dengan maksud untuk memakai atau menyuruh orang lain memakai akta itu seolah- olah keterangannya sesuai dengan kebenaran, diancam, jika pemakaian itu dapat menimbulkan kerugian, dengan pidana penjara paling lama tujuh tahun......"

Kemudian melakukan penyelidikan dan penyidikan tentang adanya tindak pidana pemalsuan surat yang terjadi dan secara pidana diproses sebagaimana konsep ketentuan pemidanaan yang berdasarkan sistem peradilan pidana (criminal justice system), namun dalam kasus ini seolah tidak dilakukan sebagaimana ketentuan hukum pidana. Bahkan penegak hukum seolah melakukan penegakan hukum asalasalan saja (underestimate) dan berakhir dengan penghentian penyidikan (SP3), karena kasus tidak terbukti dan tidak memenuhi syarat adanya tindak pidana pemalsuan surat (surat keterangan hibah).

Sebenarnya kasus tersebut memenuhi persyaratan delik pidana pemalsuan surat sebagaimana Pasal 266 ayat (1) KUHP, dan jika kasus dinyatakan "telah kedaluwarsa" oleh pihak penyidik kepolisian, menurut Pasal 84 ayat (1) berbunyi: “...... dan mengenai daluwarsa lamanya kejahatan sama dengan tenggang daluwarsa bagi penuntutan pidana....." Dengan ketentuan tersebut sebenarnya keliru kalau kasus telah kedaluwarsa, karena kasus dilaporkan ke pihak kepolisian belum ada satu tahun sedangkan ancaman hukuman penjara tujuh tahun.

Surat Pemberitahuan Penghentian Penyidikan (SP3) berdampak pelapor putus asa dan mencari hukum sendiri (eigenrechtsting) karena konsep peradilan secara prosedur telah dilakukan namun gagal, karena tidak mampu mewujudkan adanya bukti dugaan adanya pemalsuan surat keterangan hibah oleh pelapor, yang mestinya pencarian bukti tersebut dilakukan oleh penyidik sendiri (secara laboratoris). Realitas pelayanan penegakan hukum dari fakta akademis yang diperoleh dalam penelitian ini, bahwa pelayanan penegakan hukum hanya berjalan kepada masyarakat dalam strata tertentu saja. Pelapor adalah korban dari suatu sistem peradilan yang ada, hukum tajam ke bawah tumpul ke atas.

Konsep peradilan yang hanya mengandalkan proses di pengadilan banyak mengalami kendala (Arief, 2012: 9) karena masyarakat pengguna hukum tidak menerima keadilan yang diharapkan, hal demikian menjadikan masyarakat jauh dari pengadilan dan kembali kepada hukum masyarakat itu sendiri. Secara teori bahwa proses pengadilan yang hanya memburu kepastian hukum semata adalah produk dari hukum Eropa Barat dengan sistem hukum civil law yang menyingkirkan kebiasaan masyarakat dalam berhukum, dengan demikian produk hukum Eropa ini adalah hukum yang harus dipelajari, tidak mampu menyesuaikan perkembangan masyarakatnya karena telah 
kehilangan kemurniannya/kealamiahannya (Rahardjo, 2003: 14).

Hukum positif dalam situasi tertentu tidak bisa mewujudkan kehendak masyarakat dalam mencapai keadilan substansial, maka diperlukan cara lain yang mampu dan aspiratif dengan menggunakan kemurnian hukum (natural law). Sebagaimana diajarkan dalam hukum progresif bahwa hukum untuk manusia, bukan untuk yang lain, berhukum yang baik adalah berhukum yang tidak meninggalkan manusia dan masyarakatnya dan bertujuan melindungi dan menyejahterakan manusia (Rahardjo, 2003: 17 ).

Penyelesaian proses pengadilan berdasarkan keputusan pengadilan tersebut di atas adalah contoh peradilan dengan proses pengadilan yang mengandalkan ketentuan perundang-undangan yang tertulis saja dan menyampingkan kebiasaan masyarakat dalam berhukum, sehingga diperoleh peradilan yang menang dan yang kalah (win lose). Demikian ini bagi korban (yang kalah) masih menaruh dendam, bukan peradilan yang diharapkan tidak ada menaruh dendam, tercapai peradilan yang win-win solution.

Harta warisan adalah harta peninggalan pewaris yang telah meninggal dunia, dalam KUHPerdata Buku ke-3 Bab X bagian ke-1 sampai bagian ke-4 Pasal 1666 sampai Pasal 1693 mengatur tentang penghibahan dari pemberi hibah kepada penerima hibah dengan memenuhi syaratsyarat yang ditentukan dalam undang-undang ini. Adapun ahli waris sah adalah ahli waris dari anak, istri pewaris yang sah. Pewaris sah inilah yang dikaji dalam penelitian ini. Sedangkan hibah adalah pemberian hibah/hak atas tanah (dalam kasus ini) yang diberikan kepada penerima hibah sewaktu masih hidup. Pengertian anak di luar kawin dalam penulisan ini diartikan anak yang tidak disahkan sebagai anak sah diakui menurut aturan undang-undang.

Berhukum progresif adalah cara berhukum yang berfondasi pada progresivitas manusia yang memandang manusia itu sebenarnya baik, cinta kasih sayang dan mempunyai sifat tolong-menolong, empati kepada sesama manusia (Rahardjo, 2006: 23-24 ). Hal demikian sesuai dengan jiwa budaya masyarakat yang cinta damai dan gotong royong (coordination synchronisation). Dari cara berhukum demikian kesepakatan menjadi hukum bagi mereka yang berangkat dari iktikad baik dan kesepakatan itu sendiri. Hartono menyebutnya sebagai filsafat hidup (weltanschaung), yang diakui oleh bangsabangsa dengan asas musyawarah mufakat (decition making by consensus) dan asas gotong royong (coordination synchronisation).

Fenomena peradilan pewarisan dengan dasar hakim menggunakan hukum positif menerapkan prosedur penerapan pasal yang ada dalam KUHPerdata dalam mencapai keadilan. Realitasnya dengan penerapan hukum positif dalam penegakan hukum di pengadilan (hasil keputusan pengadilan), masih ada dendam dari korban karena tidak mendapatkan keadilan. Bahkan beberapa hasil penelitian menunjukkan bahwa penggunaan hukum/penegakan hukum dengan proses pengadilan banyak kecewanya karena berjalan dengan prosedur yang lama, dengan birokrasi yang berbelit (kaku), tidak beretika/bermoral, dan justru dalam praktik banyak melanggar hak asasi manusia (HAM) dan hasil keputusannya pun tidak sebagaimana yang diharapkan masyarakat/pengguna hukum, karena tidak mencapai keadilan (Dominikus, 2013: 9).

Konflik pewarisan dan hibah adalah perselisihan antara dua pihak atau lebih yang satu 
pihak mewaris dan pihak yang lain memperoleh hak atas tanah (harta) dari pemberian hibah. Kedua permasalahan ini menjadi penting karena banyak timbul di masyarakat yang berakibat kerugian bagi ahli waris sah, karena hartanya telah dihibahkan kepada orang lain yang tidak diberitahu sebelumnya. Alhasil pewaris sah tidak mendapatkan bagian. Penelitian ini dimunculkan karena terjadi konflik yang tidak menguntungkan ahli waris sah (istri dan anak almarhum).

Halini karena hakim dalam mengadili hanya menggunakan peraturan perundang-undangan (textbook), dan pencarian keadilan hanya mengandalkan hukum perdata (KUHPerdata) warisan Belanda yang menggunakan civil law system yang mengandalkan adanya penerapan hukum positif (buatan Eropa Barat) dengan mazhab positivisme hukum yang memandang bahwa dengan penerapan pasal secara prosedur dalam penegakan hukum maka sudah tercapai keadilan. Realitasnya hanya pencarian kepastian hukum semata belum tercapai keadilan dan kemanfaatan. Terbukti masyarakat masih mencari hukum sendiri dengan jalan melakukan penuntutan agar tercapai keadilan yang diinginkan, sebagaimana Radbruck yang menyatakan tujuan hukum untuk mencapai nilai keadilan, kemanfaatan, dan kepastian hukum.

Dalam penelitian Putusan Nomor 95/ PDT.G/2008/PN.BKS, penegakan hukum dalam mengadili perkara pewarisan, mengandalkan prosedur penerapan pasal yang dalam implikasinya penegakan hukum demikian semata hanya mengandalkan bukti (pembuktian), dalam memutus perkara yang pada dasarnya hanya upaya pencapaian kepastian hukum semata (Samekto, 2012: 6). Dalam kasus penghibahan ini berwujud surat keterangan hibah, yang dianggap sudah mencapai keadilan, realitasnya telah memarginalkan faktor-faktor behavior dan realitas masyarakat (korban ahli waris sah) yang sebenarnya. Alhasil dalam kasus penghibahan ini dimenangkan tergugat, karena mampu membuktikan adanya surat keterangan hibah. Hakim memutus tanpa adanya pertimbangan moral/etik/perasaan/naluri.

Putusan yang demikian menaruh dendam (dari korban ahli waris sah) karena keputusan pengadilan tidak mencapai keadilan bagi korban. Demikian fakta dari penerapan hukum di Indonesia. Hakim dalam memutus perkara (pewarisan karena hibah), realitasnya pencapaian nilai keadilan substansial dengan pertimbangan moral/etic justru ada di balik prosedural hukum (Samekto, 2012: 10).

Cara berhukum modern yang mengandalkan prosedur hukum yang notabene berusaha mencapai kepastian hukum saja yang jauh dari nilai keadilan dan kemanfaatan, seakan sebagai berhala/sebagai bahaya laten kehidupan sistem hukum di Indonesia masa kini dan masa yang akan datang, jika penegakan hukum tidak menggunakan hati/perasaan. Fenomena ini menjadi tanggung jawab semua pengguna hukum, para akademisi (pengkaji hukum) yang mestinya tidak hanya berteori di kampus, tapi lebih pada action/praktik hukum di lapangan melaksanakan tugas mulia bersama-sama penegak hukum dan lembaga pembuat hukum melakukan "amar ma'ruf nahi munkar." Bahwa hukum yang tidak berperikemanusiaan harus direformasi, direkonstruksi menjadi hukum yang ramah, yang progresif, menjalankan hukum sebagai suatu amanah, ibadah hanya mengharapkan rahmat dan ridho Tuhan Yang Maha Kuasa, karena semua keputusaan hakim akan dipertanggungjawabkan sesuai dengan perbuatan di hadapan-Nya. 
Hukum modern (asal Eropa Barat) ini tidak sesuai dengan jiwa budaya bangsa Indonesia (volkgeist) sebagaimana falsafah pandangan hidup bangsa Indonesia "Pancasila" (Hartono, 1991: 7). Perkembangan hukum menunjukkan bahwa hukum positif/cara-cara kapitalis berhukum/hukum modern telah mendominasi praktik hukum dan pengajaran di Indonesia (Samekto, 2012: 23), yang jelas tidak bercermin pada jiwa dan budaya bangsa (volgeist) masyarakat Indonesia yang cinta damai dan keakraban dalam kekeluargaan (silaturahmi).

Demikian sistem hukum Indonesia jika hanya menerapkan sistem hukum model civil law system semata, jelas sulit untuk berupaya mencapai keadilan (searching for the justice), maka perlu peranan penegak hukum dalam menggunakan sistem hukum yang bernuansa moral/etik yang disesuaikan dengan budaya dan jiwa bangsa Indonesia dalam berhukum. Pola berhukum progresif dengan sistem hukum common law (Samekto, 2012: 40-44) yang selalu berupaya dalam mencari kebenaran dan keadilan (searching for the justice and the truth) dengan tidak meninggalkan perilaku (behaviour) dalam berhukum dan tidak semata melakukan penerapan peraturan perundang-undangan.

Lembaga pembuat hukum (badan legislatif) di dalam memproduksi hukum seyogianya menghentikan substansi hukum yang bersifat subjektif. Jangan mau dibeli dan jangan hanya menggunakan substansi produk hukum yang semata berasal dari subjektifitas intelektual pembuatnya yang tidak terjun langsung melihat realitas keadaan masyarakat sesungguhnya. Formulasi hukum hendaknya memuat aspirasi yang didasarkan pada nilai-nilai keadilan Pancasila (Wignjosoebroto, 2012: 4-5).
Dalam tinjauan pustaka ini, untuk lebih memberikan penjelasan tentang pokok permasalahan, penulis menggunakan presentasi pola berhukum progresif Rahardjo. Berdasarkan progresivitas manusia, yang memandang secara alami bahwa manusia itu sebenarnya baik, empati dan tolong-menolong, saling sayang-menyayangi (penuh kasih sayang) antar sesama manusia, oleh karena adanya intervensi yang masuk dari suatu kepentingan tertentu, telah mengubah manusia dari sifat dasarnya. Dengan demikian manusia dan masyarakatnya telah kehilangan kemurniannya, maka situasinya telah berubah menjadi situasi yang modern. Dengan menggunakan hukum modern (sebagaimana penerapan berhukum dengan menggunakan hukum positif) yang berlandaskan bukti menggunakan rasionalitas semata sebagai ujung tombak pencapaian keadilan, yang mengutamakan hedonisme sebagai tujuan dari pada nilai-nilai keadilan, sesuai dengan perkembangan masyarakat modern dewasa ini (Rahardjo, 2007: 7).

Berangkat dari dasar progresivitas manusia, hukum progresif berdamai dengan alam melakukan pencarian, pembebasan, dan pencerahan. Memandang bahwa hukum untuk manusia bukan untuk yang lain dan berhukum yang baik adalah berhukum yang tidak meninggalkan manusia dan masyarakatnya, serta tujuan hukum untuk mencapai keadilan substantif yang melindungi dan menyejahterakan manusia.

Solusi alternatif dalam mengatasi konflik pewarisan dan hibah adalah dengan menggunakan hukum yang lebih bermoral dalam mengatasi kemapanan yang tidak berperikemanusiaan. Hukum progresif berkelit dan selalu mengkritisi ketidakadilan, membentuk ide baru dalam membangun hukum baru (theory building), hukum harus mampu melindungi, membahagiakan, 
dan menyejahterakan bagi penggunanya. Ketika hukum tidak bertujuan demikian, berarti hukum belum mampu sebagai instrumen dalam pencapaian tujuan nilai hukum dalam mencapai keadilan, kemanfaatan, dan keadilan.

Cara berhukum progresif (Rahardjo, 2010: 168-169) memandang bahwa di dunia ini tidak hanya ada satu tipe cara berhukum. Ada satu tipe yang hanya menerapkan bunyi pasal-pasal dalam peraturan perundang-undangan, dan dengan bertindak yang demikian sudah tercapai keadilan. Namun keadilan yang diperoleh justru di balik prosedural tadi (Samekto, 2012: 3337). Tipe cara berhukum yang kedua adalah peraturan perundang-undangan sebagai panduan moral untuk secara kreatif mengkritisi untuk bertindak lebih lanjut dalam memandang manusia dan masyarakatnya dalam berhukum dengan menjelaskan, mengkritisi, kemudian membangun teori baru (theory building) dalam upaya pencarian nilai keadilan (searching for justice). Berkaitan dengan penelitian ini bahwa jika tidak tercapai keadilan dalam berhukum di pengadilan, ada cara lain untuk memperoleh keadilan yakni penyelesaian di luar pengadilan (Rahardjo, 2005a: 11-14).

\section{METODE}

Metode penelitian ini adalah metode penelitian socio legal yang tidak hanya mengkaji peraturan perundang-undangan saja namun juga perilaku (behaviour). Pendekatan yang dilakukan dengan menggunakan pendekatan induktif, di mana fakta realitas masyarakat dapat digunakan sebagai dasar adanya perubahan. Penelitian ini bertujuan untuk mengembangkan kebijakan formulasi dengan cara berhukum positif dalam penyelesaian konflik pewarisan dan hibah berdasarkan hukum progresif dari hasil Putusan Nomor 95/PDT.G/2008/PN.BKS yang dipandang kurang mencapai keadilan dari pihak penggugat.

Tradisi penelitian ini adalah penelitian dengan pendekatan kualitatif (qualitative research), yaitu tradisi penelitian yang tidak mengandalkan pada banyaknya data, tetapi pada kedalaman data. Untuk memperoleh data yang mendalam, dilakukan penelitian lapangan dengan wawancara menggunakan narasumber yang dipandang kompeten untuk menjelaskan fenomena terkait. Melalui penelitian kualitatif mencakup pendekatan metode dan analisis induktif terhadap subjek kajiannya.

Kajian penelitian ini berparadigma post-positivisme dengan pendekatan induktif. Penelitian dalam paradigma tertentu (postpositivisme) harus berbasis pada konsistensi ontologis, epistemologis, dan methodologis. Secara ontologis di dalam penelitian ini, aturanaturan/hukum dikonsepsikan sebagai sebuah realitas yang tidak dimaknai sekadar aturan yang telah memenuhi aspek-aspek dalam ajaran positivisme tetapi akan dikaji keberlakuannya dan efektivitasnya untuk menyelesaikan kasuskasus pewarisan dan penghibahan.

Secara epistemologi dalam penelitian ini peneliti bukan sekedar menganalisis berdasar keberlakuan aturan-aturan hukum saja, tetapi mengkaji faktor-faktor di luar norma hukum yang memengaruhi pelaksanaan aturan-aturan hukum, terkait dengan pewarisan dan penghibahan pada Putusan Nomor 95/PDT.G/2008/PN.BKS. Dari penelitian ini diharapkan dapat diketahui; apakah putusan tersebut benar-benar menuntaskan persoalan. Analisis difokuskan pada penegakan hukum atas Putusan Nomor 95/PDT.G/2008/ PN.BKS. 
Terkait dengan konteks penelitian ini yaitu menemukan solusi penyelesaian alternatif di luar pengadilan dengan menggunakan cara pendekatan kemanusiaan, dari hati ke hati dengan cara dikumpulkan (conciliation) kemudian dilakukan mediasi dalam pencapaian kemufakatan agar tercapai keadilan kedua belah pihak. Karena selama ini sistem hukum yang dipakai (hukum positif) adalah sistem hukum yang berdasarkan bukti-bukti. Di sini terjadi kontradiksi antara anggapan masyarakat yang menggunakan hukum rakyat, hukum kebiasaan yang memandang jika benar sampai manapun pasti menang.

\section{HASIL DAN PEMBAHASAN}

Penyelesaian konflik pewarisan akibat hibah berdasarkan Putusan Nomor 95/ PDT.G/2008/PN.BKS, keputusan hakim pada sidang pengadilan menolak gugatan penggugat (ahli waris sah) yang konon tidak mampu membuktikan ketidakabsahan surat keterangan hibah. Konflik penghibahan dan pewarisan menjadi penting untuk diteliti, karena banyak persoalan-persoalan penghibahan dan pewarisan berujung dengan konflik yang menimbulkan korban, bahkan terjadi kejahatan terhadap sesama ahli waris dan anak di luar kawin di Indonesia.

Anak luar kawin memiliki surat keterangan hibah. Walaupun hibah tersebut cacat hukum, dibuat penghibah seolah sewaktu masih hidup, tidak ada tanda-tanda pewaris (almarhum) memberikan hibah seluruh hartanya tanpa memberitahu istri dan anaknya. Pewaris dikenal sebagai bapak yang jujur, sehat jasmani rohani, dan mengerti istri dan anaknya kelak yang akan mewarisi hartanya. Tidak mungkin untuk menghibahkan seluruh harta kepada orang lain tanpa memberitahu kepada keluarga (istri dan anaknya). Fenomena hukum tersebut menggambarkan betapa lemahnya peradilan di Republik ini. Konflik yang berkepanjangan dan berakhir di pengadilan, tidak sesuai dengan harapan masyarakat (korban) pencari keadilan yang berakibat masyarakat mencari hukum dengan main hakim sendiri (eigenrichting).

Hakim terpasung dengan ketentuan formal hukum, yang hanya mengandalkan law and logic atau law and logic bound yang memarginalkan behaviour. Hanya memburu kepastian hukum saja dan mengebiri keadilan substansial, tidak menggunakan perasaan/hati nurani/moral/ etik. Korban (ahli waris anak dan istri sah) dalam posisi lemah sebagai wong cilik yang tak berdaya walaupun sebagai ahli waris sah, harus menyerah kalah ketika hakim pengadilan negeri, pengadilan tinggi (banding) dan Mahkamah Agung dalam keputusan kasasinya menyatakan menolak gugatan penggugat dan menghukum penggugat (ahli waris anak dan istri sah) dengan harus membayar biaya perkara selama sidang di pengadilan. Hal ini memberi pelajaran kepada kita bahwa hak mewaris dari ahli waris sah digagalkan dengan surat keterangan hibah.

Dari fenomena tersebut di atas, bahwa positivisme hukum yang telah mendominasi peradilan mengalami kebuntuan karena tidak mendapatkan keadilan substantif. Oleh karena itu dianggap perlu ada kajian sosiologi yang lebih mendalam yang mampu menjelaskan kebuntuan positivisme hukum dimaksud, yakni dengan cara mengembangkan logika berhukum secara progresif yang mampu menjelaskan (explain), mengkritisi kemudian membangun ide baru (theory building). Mengingat kajian hukum tidak hanya pada ranah normatif yuridis/ penerapan peraturan perundang-undangan saja, 
tapi juga pada non-normatif yuridis/evaluasi dan pengembangan dengan mengambil pola berhukum progresif yang meninggalkan manusia dan masyarakatnya dalam berhukum, dalam upaya mencari keadilan (searching for justice).

Kebijakan dari pengembangan pola berhukum progresif dapat digunakan sebagai kebijakan dalam menentukan langkah demi terwujudnya keadilan substantive (Rahardjo, 1972: 23-24) tentang penyelesaian konflik pewarisan dan hibah berdasarkan hukum progresif pada kajian Putusan Nomor 95/ PDT.G/2008/PN.BKS yang dipandang kurang mencapai keadilan dari pihak penggugat dan dicari solusinya dengan pendekatan moral kemanusiaan. Demikian realitas yang ada dalam praktik pengadilan, di mana hakim hanya mengandalkan proses formalisme hukum (textbook) dalam menegakkan hukum, dengan mengesampingkan moral kemanusiaan. Dari fenomena tersebut penulis tawarkan agar hakim berparadigma cara berhukum progresif yang berlandaskan progresivitas manusia bahwa sebenarnya manusia itu baik, penuh empati, tolong-menolong dan memiliki rasa kasih saying (Rahardjo, 2009: 4-7).

Secara ekonomi menjadi persoalan tersendiri karena menerima nasib sebagai orang yang kehilangan harta satu-satunya peninggalan mendiang suaminya (tanah, rumah, dan penghasilan lainnya), secara sosial budaya ada kesenjangan, kohesi, dan harmonisasi menurun, terjadi semacam beban moral dan malu kepada sesama warga di lingkungan tempat tinggal. Dari fenomena tersebut timbul suatu permasalahan sebagai bahan kajian dalam penelitian ini, dengan harapan ada penyelesaian yang lebih arif dan bijaksana yang bertumpu pada nilai-nilai kemanusiaan, ada suatu empati kalau memang kalah di pengadilan. Demikian paradigma hukum positif dalam penerapannya secara prosedural yang mengutamakan "pembuktian." Keputusan pengadilan ada pihak yang kalah dan ada pihak yang menang dan bagi korban (ahli waris sah) masih menaruh dendam, karena tidak mendapatkan keadilan.

Pertimbangan hakim menolak permohonan kasasi karena keberatan yang diajukan penggugat tidak dapat dibenarkan, karena judex facti tidak salah menerapkan hukum. Lagi pula mengenai penilaian hasil pembuktian yang bersifat penghargaan tentang suatu kenyataan, hal mana tidak dapat dipertimbangkan dalam pemeriksaan pada tingkat kasasi. Karena pemeriksaan dalam tingkat kasasi hanya berkenaan dengan adanya kesalahan penerapan hukum, adanya pelanggaran hukum yang berlaku, adanya kelalaian dalam memenuhi syarat-syarat yang diwajibkan dalam peraturan perundang-undangan yang mengancam kelalaian itu dengan batalnya putusan yang bersangkutan, atau bila pengadilan tidak berwenang atau melampaui batas wewenangnya, sebagaimana yang dimaksud dalam Pasal 30 Undang-Undang Nomor 14 Tahun 1985 jo. Undang-Undang Nomor 5 Tahun 2004. Dalam putusan kasasi menyatakan bahwa putusan judex facti dalam perkara ini tidak bertentangan dengan hukum dan/atau undang-undang, maka permohonan kasasi yang diajukan oleh para pemohon kasasi tersebut harus ditolak, maka para pemohon kasasi dihukum membayar biaya perkara tingkat kasasi ini.

Dari fondasi demikian ada rasa senasib seperjuangan (expride corps) kepada sesama manusia. Fenomena demikian seyogianya hakim dalam memutuskan perkara di pengadilan hendaknya mempertimbangkan secara moral. Tidak kaku hanya berdasarkan hukum tertulis 
saja yang bertindak dalam memutus perkara dan condong bersifat asal-asalan saja (underestimate), namun juga menimbang kepentingan, nasib si kalah yang harus melangkah bagaimana dalam memperjuangkan haknya, harus menerima sebagai si miskin karena tidak jelas dengan keputusan pengadilan kalah kemudian harus bertempat tinggal di mana.

Kebiasaan masyarakat dengan hukum rakyat yang merupakan fundamental dari Sistem Pembangunan Hukum Nasional (Hartono, 2011a: 9-10), yang merupakan kebiasaan dalam kehidupan berhukum setiap hari di masyarakat, harapan masyarakat warga agar hukum rakyat dimunculkan, dilaksanakan sebagai hukum/ aturan yang digunakan agar tercapai keadilan substansial. Adanya keinginan agar digunakan hukum rakyat dan hukum negara, realitasnya hukum rakyat banyak yang dikalahkan, model budaya manusia abad sekarang terutama generasi-generasi kaum borjuis yang berpaham modern, kental dengan intervensi kapitalisme, condong menggunakan hukum negara daripada hukum/budaya rakyat.

Budaya yang terintervensi oleh kepentingan kapitalisme yang selalu menggunakan hukum modern berdampak terhadap penegakan hukum Indonesia, yang dilakukan pada lini criminal justice system dalam penegakan hukum yang hanya mengandalkan penerapan pasal dalam meraih kepastian hukum/hanya berhukum secara linier tidak menggunakan perasaan/moral/etik. Sebagaimana penyidik polri yang menerima laporan pengaduan kasus pewarisan dan hibah yang dilaporkan pewaris sah (dalam penelitian ini) ke Polres Bekasi dengan pengaduan adanya tindak pidana pemalsuan surat, yang berakhir dinyatakan tidak cukup bukti dengan Surat Pemberitahuan Penghentian Penyidikan (SP3).
Keikutsertaan penegak hukum (polri), seyogianya penegakannya juga tidak semata terpaku oleh ketentuan legalitas formalisme (law and logic atau law and logic bound) yang bersifat linier tapi lebih melihat kenyataan/ realitas masyarakat. Pelapor yang sangat minta pertolongan akan keadilan, mestinya diupayakan dengan melihat dengan cara berpikir logika dengan pola berhukum progresif, melihat hukum dengan kenyataan masyarakat. Bukan manusia (masyarakat) yang menyesuaikan hukum, tapi sebaliknya hukum yang menyesuaikan manusia. Pola berhukum progresif terfokus pada adagium "hukum untuk manusia" bukan untuk yang lain dan hukum yang benar adalah "hukum yang tidak meninggalkan manusia dan masyarakatnya, bertujuan untuk mewujudkan keadilan substantif' (Suteki, 2004: 7).

Hakim berparadigma bahwa keadilan sudah diperoleh ketika telah dilaksanakan penegakan hukum secara prosedural. Kurang adanya pemahaman bahwa hanya dengan "prosedur hukum" saja, berarti hanya berupaya dalam meraih kepastian hukum dan hukum bukan hanya kepastian hukum saja tapi juga kemanfaatan dan perolehan keadilan bagi pengguna hukum. Maka perlu adanya penegakan hukum yang berpola berhukum secara progresif, yang berhukum dengan melihat manusia dan masyarakatnya demi tercapainya keadilan substantif.

Mengkaji ketentuan penghibahan menurut peraturan perundang-undangan KUHPerdata Buku ke-3 Bab X bagian ke-1 sampai bagian ke-4 Pasal 1666 sampai Pasal 1693 mengatur tentang penghibahan dari pemberi hibah kepada penerima hibah dengan memenuhi syarat-syarat yang ditentukan dalam undang-undang ini, antara lain penghibah dalam keadaan sehat jasmani dan rohani, tentunya masih hidup dan cakap. 
Penerima hibah pun cakap memenuhi syaratsyarat sebagai penerima hibah dan harta benda (rumah dan tanah) yang akan dihibahkan sudah ada. Dalam klausul tidak mengatur apakah dalam penghibahan harus diketahui ahli waris yang lain atau tidak, ternyata dalam praktik di masyarakat penghibahan tidak harus diketahui ahli waris sah yang lain dan tidak membatasi bagian ahli waris sah. Dalam praktik bebas, penghibah berhak menghibahkan seluruh harta warisannya kepada penerima hibah.

Hal demikian menjadi kendala dalam pewarisan dan rawan akan terjadinya masyarakat main hakim sendiri (eigenrichting). Lebihlebih para ahli waris yang sah, karena cara menang dalam berperkara di pengadilan hanya berdasarkan bukti (dalam hal ini hibah). Hakim tidak melakukan penyelidikan akan kebenaran akta hibah yang disodorkan tergugat dan banyak cara lain yang terkait dengan bukti (formal) di pengadilan sangat amat tidak menguntungkan pihak masyarakat (korban/ahli waris sah). Masyarakat warga tetap berprinsip dengan pendiriannya yang tulus, ikhlas, dan benar, mereka beranggapan kalau yang benar sampai pengadilan manapun tetap menang.

Surat keterangan hibah dinyatakan sebagai akta hibah yang cacat karena tidak sesuai ketentuan undang-undang KUHPerdata, di mana hibah harus diketahui oleh ahli waris yang sah (istri dan anak pewaris), dan juga pemberian hibah tidak melanggar bagian dari ahli waris yang lain. Hibah dilakukan semasa masih hidup dan tidak boleh menghibahkan seluruh harta kekayaan penghibah (yang meliputi tanah dan bangunan, contoh kasus dengan luas 4.000 $\mathrm{m} 2$ ), karena melanggar bagian ahli waris yang lain. Apalagi penghibahan berlangsung tanpa diketahui ahli waris sah yang lain. Dalam hal ini anak luar kawin tidak diakui menguasai harta pewaris berdasarkan surat keterangan hibah. Alhasil ketika ahli waris sah mengambil dan menduduki secara wajar harta mendiang suaminya ternyata bermasalah kepada anak luar kawin tidak diakui yang membawa bukti hibah dan melakukan pembalikan nama atas sertifikat hak milik terhadap dirinya.

\section{Hasil beberapa analisis penelitian} (pada objek penelitian) realitasnya banyak kejanggalan tentang pelaksanaan penghibahan. Dari hasil penelitian pada Putusan Nomor 95/ PPT.G/2008/PN.BKS, antara lain ada kejelasan yang berbeda dari PPATS/Camat Bekasi yang terdahulu dan sekarang dari buku desa yang mencatat tentang peralihan hak atas tanah. Berbeda tentang kejelasan keberadaan kebenaran dari penghibahan. Kejelasan PPATS yang satu menyatakan bukan hibah tapi jual beli, yang lain menyatakan dari hibah. Menurut saksi desa yang akrab dan menjadi pesuruh almarhum pewaris menyatakan tidak pernah dilakukan penghibahan antara almarhum dengan anak luar kawin.

Demikianlah produk keputusan dari cara berhukum prosedural penerapan pasal yang mengedepankan logika/rasionalitas, sehingga moral tertutup, membuat orang kejam terhadap kehidupan itu sendiri. Produk hukum modern (hukum positif) dari Eropa Barat jelas secara moral tidak sesuai dengan budaya bangsa. Pengadilan bukan lagi tempat mengadili dalam rangka mencari keadilan tapi ajang bisnis yang mencari menang dan kalah (Hartono, 2011b: 41-46). Cara berhukum demikian (modern) adalah merupakan akibat dari tidak terkavernya kebutuhan akan kepentingan masyarakat yang makin maju dan perkembangan hukumnya (Rahardjo, 2006: 8-11). 
Dari cara berhukum demikian dalam penerapan hukum hendaknya penegak hukum tidak hanya berpikir linier tapi juga menggunakan hati nurani, agar hukum mampu mengakomodir semua kepentingan masyarakatnya. Sebagaimana hukum tidak hanya telaahannya bukan hanya hukum sebagaimana yang biasa dipahami secara tradisional. Ilmu hukum dewasa ini dituntut untuk menjalankan tugas menciptakan hukum baru dalam rangka mengakomodasi semua kepentingan-kepentingan yang tumbuh dalam hubungan kemasyarakatan yang dalam perkembangannya semakin kompleks (Sidharta, 2013: 2). Demikian hukum mampu melindungi dan menyejahterakan. Seyogianya hakim dalam memutuskan perkara (penghibahan) ada upaya lain yang diselaraskan dengan kepentingan kemanusiaan, dengan mengambil jalan tengah/ mediasi memberikan hak sepantasnya kepada ahli waris sah dan juga pada anak luar kawin yang tidak diakui. Hukum tidak harus kaku namun lentur memahami harapan dari kepentingan dan realitas keberadaan masyarakat pengguna hukum dan mewujudkannya. Hukum bukan berada di ruang hampa dan berhadapan dengan sesuatu yang abstrak, namun berada dalam suatu ruangan yang nyata dan berhadapan dengan manusiamanusia (Rahayu, 2005: 14).

Sesungguhnya pengadilan lah yang mampu mengadili dengan adil dalam sistem peradilan formal dalam kasus hibah dan pewarisan sebagaimanatugas dan fungsinya (jobdescription) pengadilan. Hanya kadang penggunaan hukum secara formal yang harus menempuh syarat adanya pembuktian dan pembuktinya menjadi menang di pengadilan tanpa pertimbangan moral kemanusiaan. Bagi yang tidak mampu membuktikan kepemilikan, hak mewarisi menjadi kalah. Pengadilan belum mampu mengakomodasi keinginan masyarakat yang percaya bahwa yang benar sampai pengadilan pun akan menang tanpa harus membuktikan kebenaran itu.

Fenomena tersebut menyebabkan kontroversi antara hukum masyarakat/hukum rakyat dengan hukum negara. Hukum negara siapa yang dapat membuktikan secara formal dialah yang menang tanpa berpikir panjang tentang keberadaan (asal-usul) dan tidak mempertimbangkan nilai yang sebenarnya dari bukti itu. Demikian hukum formal memandang adil bagi yang mampu membuktikan, karena paradigma "keadilan" bagi pengadilan adalah kemampuan pembuktian, melaksanakan penerapan hukum secara prosedural, yang pada dasarnya paradigma prosedural ini hanyalah mencari kepastian hukum saja. Hukum tidak hanya bertujuan dalam kepastian hukum saja tapi hukum harus bermanfaat dan berkeadilan.

Berkenaan dengan hal tersebut di atas, perkembangan ilmu sosiologi hukum menguntungkan bagi perkembangan hukum itu sendiri. Ilmu hukum yang selalu berkembang yang selalu mengimbangi perkembangan masyarakat dan hukum harus mampu mengakomodasi semua kepentingan masyarakat dan mewujudkannya. Tanpa sosiologi hukum perkembangan hukum dalam menegakkan keadilan (dengan menggunakan hukum positif), niscaya hukum tak mampu dijelaskan dalam perkembangannya (Rahardjo, 2005b: 7-11).

Cara-cara sosiologi hukum yang mengkritisi penegakan hukum berlandaskan bahwa hukum tak mampu mewujudkan keadilan/berhukumnya tidak berpedoman pada pencapaian keadilan substantif, tidak nilai. Keadilan dianggapnya sudah tercapai ketika melakukan suatu penerapan prosedur hukum, padahal keadilan itu ada di 
balik prosedur hukum (Samekto, 2012: 33-345). Dengan demikian masyarakat lalu mencari hukum sendiri (eigenrichting). Idealnya penyelesaian kasus pewarisan tersebut di atas dalam perspektif hukum progresif, ahli waris sah (istri dan anak sah almarhum) dapat memperoleh haknya sebagai ahli waris. Dengan dasar kemanusiaan dalam sudut pandang etik/moral kemanusiaan, yang berangkat dari kemurnian hati/progresivitas manusia, bahwa manusia itu sebenarnya baik, penuh empati, dan kasih sayang terhadap sesamanya.

Tidak adanya pertimbangan moral, ketika dalam penegakan hukum dan terjadi penyelewengan terhadap hukum yang berakibat tidak tercapainya tujuan hukum. Sebagai instrumen pencapaian tujuan hukum yang melindungi dan menyejahterakan, hukum progresif terpanggil untuk menjelaskan, mengkritisi kemudian membangun teori baru (theory building). Hukum progresif memandang bahwa hukum modern (cara hukum positif) adalah cara berhukum yang harus dipelajari, karena hal demikian kehilangan keasliannya (kealamiahannya) karena berdasarkan rasio intelektual kepentingan pembuatnya. Jika diterapkan hukum yang dipelajari tersebut tidak mampu mengakomodasi kepentingan masyarakat dan mewujudkannya/tidak mampu berbuat adil (Rahardjo, 2005a: 12-13).

Wajah hukum yang demikian tidak bergeser, bahkan telah mendominasi praktik hukum dan pengajaran hukum di Indonesia. Hukum dikonsepsikan sebagai undang-undang tertulis yang dibawakan oleh kaum profesionalisme (para hakim dalam lini criminal justice system dan pengacara). Secara tidak sadar kaum profesional itu telah mensosialisasikan bahwa demikianlah hukum, maka pengadilan tidak lagi sebagai pencari keadilan tapi lebih digunakan sebagai ajang bisnis komersial. Bahkan dinyatakan sebagai wadah pertempuran yang mencari kalah menang dalam berperkara, yang berbau materi. Jika demikian perkembangannya maka hukum tak lagi dicintai masyarakat dan tidak digunakan sebagai instrumen pencari keadilan (searching for justice) dan kebenaran (searching for thruth).

Cara berhukum progresif dalam pencapaian keadilan substantif yakni dengan berhukum yang tidak meninggalkan manusia dan masyarakatnya, hakim seyogianya mampu mencari hukum sendiri demi tercapainya keadilan substantif. Berkaitan dengan perolehan pewarisan anak luar kawin yang tidak diakui secara prosedur hukum dan ahli waris yang sah (istri dan anak) hendaknya hakim di pengadilan memosisikan yang seadiladilnya, sehingga tidak terjadi konflik dengan keputusan hakim di mana ahli waris sah tidak mendapatkan bagian sama sekali (tanah dan bangunan) almarhum.

Ahli waris sah dalam pandangan hukum adat, tidak lepas dari kebiasan adat dalam menyikapi pewarisan yang demikian. Dalam adat kebiasaan (di Jawa), anak yang diangkat dan dinyatakan sah jika diambil dari orang tuanya sejak lahir, diberkati dan diberi nama dianggap sebagai anak sah (karena sejak lahir) sudah diambil sebagai anak. Hak mewaris anak yang demikian sama seperti anak kandung dalam memperoleh hak mewaris (hasil penelitian peneliti dalam memandang realitas masyarakat pedesaan di Jawa Tengah dalam menyikapi anak angkat yang diangkat sejak lahir), namun tidak seperti pada realitas pewarisan dan penghibahan dalam kasus ini. Anak luar kawin tidak diakui dinyatakan menang dalam keputusan pengadilan karena mampu memperlihatkan bukti penghibahan dan menguasai seluruh harta (tanah dan bangunan) 
almarhum dan menyingkirkan hak mewaris ahli waris sah.

Dalam peraturan perundang-undangan (KHUPerdata) ada mekanisme pengangkatan anak dengan menggunakan akta notaris yang dibuat di hadapan pejabat notaris (sebagai akta orisinal), yang menghadirkan orang tua anak dan pihak yang akan mengangkat anak (mengadopsi anak) kemudian didaftarkan ke pengadilan negeri. Dengan keputusan pengadilan negeri maka sahnya pengangkatan anak dapat dilakukan.

Cara berhukum proses di pengadilan dengan mekanisme sistem peradilan Indonesia dengan melalui tahapan proses (maka proses dinyatakan lama) prosedur dari menerima laporan tentang adanya suatu perkara. Kemudian penyidik yang menerima laporan mencatat semua identitas dan peristiwa yang terjadi, kemudian mengumpulkan bukti-bukti secara formal dan dilakukan penuntutan/penggugatan di pengadilan dan diadili oleh hakim yang berpedoman pada proses dengan melakukan peraturan-peraturan yang tertulis (KUHPerdata). Secara normatif warisan mendiang suaminya turun kepada anak dan istrinya, namun bisa kalah di pengadilan dengan surat akta hibah dari anak pungutnya. Secara teoritis yang demikian apakah proses pengadilan yang hanya berdasarkan aturanaturan yang tertulis dapat mengakomodasi semua kepentingan, aspirasi, dan perkembangan masyarakat. Kemudian dengan hanya menggunakan aturan apakah dapat menertibkan, mengadili masyarakat sebagaimana sedia kala (Rahardjo, 2005b: 7-11).

Hukum hendaknya tidak menyengsarakan, tapi hukum hendaknya melindungi, menyejahterakan, dan membahagiakan bagi penggunanya, demikian hukum dinyatakan bertujuan mencapai keadilan substantif. Hukum ke depan dituntut tidak hanya melindungi, membahagiakan, dan mampu mencapai keadilan bagi penggunanya, tapi lebih lagi hukum harus mampu mengakomodasi kepentingankepentingan masyarakat dengan demikian dibutuhkan penalaran hukum (Sidharta, 2013: 2-4).

Berkaitan dengan Putusan Nomor 95/ PDT.G/2008/PN.BKS di atas, seyogianya hukum harus mampu berbuat adil, melindungi, dan menyejahterakan. Ketika hukum tidak mampu berbuat demikian maka hukum tidak mampu sebagai instrumen dalam pencapaian tujuan hukum. Hasil keputusan tersebut di atas kurang mencerminkan tujuan dalam mencapai keadilan substantif dari Putusan Nomor 24591/PDT/2009 tanggal 30 Juli 2010 jo. Putusan Nomor 95/ PPT.G/2008/PN.BKS tanggal 2 September 2008. Keputusan kasasi menyatakan hal yang sama dengan keputusan Pengadilan Nomor 95/ PDT.G/2008/PN.BKS menolak permohonan kasasi penggugat dan menghukum dengan membayar seluruh biaya perkara (kasasi).

Hukum progresif berkelit dengan kemapanan yang berfondasi pada progresivitas manusia, bahwa manusia itu sebenarnya baik dan mulia, penuh empati, dan rasa kasih sayang yang tinggi kepada sesama manusia, hidup dalam kebersamaan yang tidak meninggalkan silaturahmi. Filosofi yang demikian sesuai dengan falsafah Pancasila (Hartono, 2011a: 8-9), karena memang yang demikian keinginan founding father dalam menata negara yang sesuai dengan napas jiwa dan budaya bangsa. Hukum progresif dengan cara dan logika berhukum yang progresif mengharapkan sistem hukum kembali berhukum yang tidak meninggalkan kealamiahannya dengan cara melihat manusia dan masyarakatnya, karena 
hukum untuk manusia bukan untuk yang lain dan selalu berupaya agar tercapai keadilan substantif. Ketika hukum tidak bertujuan mencapai keadilan substantif yang menyejahterakan, melindungi, dan membahagiakan, berarti bukan hukum dan hanya komitmen ketentuan bagai huruf mati yang tidak berfungsi dan menyengsarakan manusia.

Fenomena hukum positif/hukum modern perkembangannya sangat pesat sampai mendominasi bekerjanya hukum dan pengajaran pada waktu tertentu dalam penegakan hukum, akan menerima tuntutan masyarakat karena tidak mampu mewujudkan keadilan (Yusriyadi, 2004: 7). Sebagaimana pada Putusan Nomor 95/PDT.G/2008/PN.BKS tersebut di atas, masyarakat pengguna hukum resah (penggugat istri dan anak pewaris sah), tidak nyaman, tidak ada perlindungan, dan harus menerima nasib sengsara. Padahal anak dan istri mendiang suami hidup sejahtera dengan penghasilan dan kehidupan yang mewah, kemudian harus sirna ketika suaminya meninggal dunia, harta berpindah karena tiba-tiba ada penghibahan kepada seseorang yang dilaksanakan mendiang suami ketika masih hidup. Demikianlah fenomena hukum yang tidak menguntungkan dan tidak menyejahterakan bagi anak dan istri pewaris sah dan menguntungkan bagi penerima hibah (karena mampu menunjukkan adanya bukti hibah), berdasarkan bukti saja dapat menguasai dan menerobos hak milik ahli waris sah (anak dan istri).

Cara berhukum positif yang kaku, simptomatik, paradoks, dan represif hendaknya tidak membuat sengsara korban dan bangsa ini. Semua perilaku penegakan hukum yang kurang etik, kurang perikemanusiaan seakan tidak ada jalan lain menuju kesejukan hukum, bagai titik nadir yang belum ada solusinya (perkembangan hukum yang mengarah kepada moralitas manusia). Karena semua serba ditata dengan aturan, asli kealamiahan hamba Allah dalam menjaga jagat raya ini akhirnya diatur oleh rasionalisme manusia/diatur oleh sebatas pancaindra memandang kehidupan ini.

Peraturan yang terdominasi dengan rasionalitas manusia, yang akhirnyamembelenggu manusia itu sendiri. Hal-hal yang berkaitan dengan ide, filosofi yang tidak terjangkau dengan rasionalisme pancaindra manusia banyak yang tidak dilalui/dikufuri, yang sebenarnya itulah kebenaran, hakikat dari ontologi peradaban manusia sebagai hamba Allah. Akibat yang nampak dalam perkembangan peradaban manusia yang hanya menggunakan rasio dalam menyikapi hidup menjadikan manusia hamba materi yang rentan dengan sebutan sekularisme.

Sekularisme adalah sebagai suatu paham, yang menganggap materi adalah satu-satunya sarana dalam menyikapi hidup dan perkaranya (Susila, 2013: 7), dengan mengandalkan materi dalam pandangan sekularisme semua perkara akan tuntas. Realitasnya pandangan ini akan kandas ketika perkara hidup yang ditanggulangi dengan materi tidak selesai, justru menjadi permasalahan baru yang semakin besar. Menyengsarakan dan sulit ditanggulangi dengan materi. Dengan pandangan rasionalitas sekularisme, hedonisme sebagai tujuan akhir. Bukankah kita sebagai manusia berketuhanan (Pancasila), melaksanakan perintah dan menjauhi larangan-Nya.

Hukum progresif Rahardjo adalah hukum yang tidak menggunakan cara berhukum secara linier semata tapi juga menggunakan perasaan, bukan hanya menggunakan IQ semata, tapi EQ dan SQ sebagai hukum yang manusiawi. Ketika jalan tersumbat, terhalang dari kepentingan 
positivisme hukum yang menyengsarakan, buntu tidak ada jalan lagi untuk berhukum muncullah hukum progresif yang berkelit dari kemapanan cara berhukum modern dengan mendobrak memberi kejelasan (explanation), mengkritisi lalu menciptakan ide baru dalam pembaruan hukum.

Menyikapi masalah hukum positif/ hukum modern berkembang pesat mendominasi praktik dan pengajaran hukum, sebagai praktisi, akademisi, dan para penegak hukum juga pengguna hukum hendaknya mulai merenung, introspeksi diri, untuk melakukan penata ulang (rekonstruksi). Melihat ke depan sebab hukum menata berbangsa dan bernegara juga menata hidup. Mulai dari sinilah betapa pentingnya makna hukum bagi kehidupan manusia, rekonstruksi hukum menuju kehidupan yang lebih baik.

Hukum progresif adalah hukum yang lentur (flexible) dengan melihat masyarakat dan manusiamanusia yang butuh pertolongan keadilan dengan sarana hukum. Ide pola berhukum progresif yang anti kemapanan, berkelit mengkritisi kemudian membangun ide baru (theory building), sehingga tidak hanya berkutat pada hukum made in Eropa yang tidak sesuai dengan jiwa budaya (volkgeist) bangsa Indonesia (Rahardjo, 2006: 7-10).

Pandangan pola berhukum progresif dalam Putusan Nomor 95/PDT.G/2008/PN.BKS di atas, dengan menganalisis dan menjelaskan dari segi etika, kepatutan, manusiawi, dengan cara logika pun perlu dijelaskan, apakah ada ahli waris (istri dan anak sah) dari mendiang suaminya (pewaris) harus tidak menerima apapun dari harta yang ditinggalkan suaminya. Apakah wajar jika seluruh harta tanpa kecuali dihibahkan oleh almarhum (suami) kepada orang lain ketika masih hidup, dia dalam keadaan sehat jasmani rohani. Apakah dia bangga kalau seluruh harta diserahkan ke orang lain tanpa ada dalih apapun dan kemudian hari akan menyengsarakan istri dan anaknya. Kajian pengkritisan secara logika yang timbul dari hati nurani yang mestinya harus dicakup oleh hukum itu sendiri.

Dari pandangan progresivitas manusia penegak hukum seyogianya dalam menegakkan hukum harus menggunakan hati nurani, tidak hanya berhukum secara linier semata (Arief, 2001: 4-5) demi tercapainya perlindungan (defend) dan kesejahteraan (welfare). Keputusan pengadilan hendaknya memutuskan yang adil, dalam keputusan tersebut di atas dengan pertimbangan ahli waris sangat membutuhkan penghidupan dan masa depan butuh kesejahteraan dan perlindungan hukum, pertimbangan moral, walaupun secara fakta (bukti adanya hibah) penerima hibahlah yang berhak atas harta peninggalan pewaris.

\section{KESIMPULAN}

\section{Putusan Nomor 95/PDT.G/2008/PN.BKS} tanggal 30 Juli 2010 masuk kategori hukum perdata dalam putusan hak pewarisan ahli waris sah sebagai penggugat dan menggugat anak luar kawin tidak diakui yang realitasnya mampu menguasi harta almarhum pewaris, dengan menunjukkan bukti surat keterangan hibah. Walaupun surat hibah tidak memenuhi syarat, tapi tetap keputusannya menang sampai tingkat kasasi dengan ditolaknya gugatan penggugat dan menghukum dengan sanksi pembayaran biaya perkara.

Dapat disimpulkan bahwa penyelesaian konflik pewarisan akibat hibah berdasarkan hukum progresif anak luar kawin tidak diakui mampu menguasai harta pewaris, termasuk bagian ahli waris sah. Karena terbukti anak luar 
kawin menerima hibah dari almarhum/pewaris ketika masih hidup dan surat keterangan hibah dimaksud dapat dibuktikan di sidang pengadilan. Dalam pandangan hukum progresif lebih melihat dengan cara pandang logika berhukum progresif dengan fondasi progresivitas manusia bahwa manusia sebenarnya baik, empati, penuh rasa kasih sayang terhadap sesama. Maka pandangan hukum progresif, bahwa hukum untuk manusia bukan untuk yang lain, berhukum yang baik berhukum yang tidak meninggalkan manusia dan masyarakatnya.

Tujuan berhukum demi tercapainya keadilan substansial dan memandang hukum bukan suatu institusi yang final tapi berproses (law a process law in the making). Berangkat dari pandangan hukum progresif terkait dengan peradilan waris dan hibah tersebut di atas seyogianya penyelesaiannya tidak meninggalkan etika moral kemanusiaan/menggunakan perasaan. Dengan pendekatan kemanusiaan ada rasa belas kasihan (empati) kepada korban (anak dan istri pewaris/almarhum). Seyogianya hakim mampu berbuat bijak (mampu mencari hukum) dengan suasana yang demikian, juga anak luar kawin untuk menyerahkan sebagian harta peninggalan almarhum demi kelangsungan hidup keluarganya (almarhum), demi tercapai keadilan antar pihak.

\section{DAFTAR ACUAN}

Arief, B.N. (2001). Masalah penegakan hukum \& kebijakan penanggulangan kejahatan. Bandung: PT Citra Aditya Bakti.

(2012). Mediasi Penal Penyelsaian Perkara Pidana di Luar pengadilan, Pustaka Magister Semarang.
Dominikus, R. (2013). Penyelesaian sengketa tanah adat dalam perspektif kearifan lokal pada masyarakat Ngadhu Bhaga, Kabupaten Ngada - NTT. Masalah-Masalah Hukum Jilid 42(3), 9.

Hartono, C.F.G.S. (1991). Politik hukum menuju satu sistem hukum nasional. Bandung: Alumni. . (2011a). Mencari makna nilai-nilai falsafah di dalam Pancasila sebagai filsafat hidup bangsa dan Negara Republik Indonesia. Forum dialog nasional bidang hukum dan non hukum yang diselenggarakan oleh BPHN, Jakarta.

(2011b). Beberapa pemikiran tentang pembangunan sistem hukum nasional Indonesia. Bandung: PT Citra Aditya Bakti.

Rahardjo, S. (1972). Hukum dalam kerangka ilmuilmu sosial dan budaya. Majalah Ilmiah Masalah-Masalah Hukum, 1, 23-24.

(2003). Hukum responsif, perkumpulan untuk pembaruan hukum, berbasis masyarakat dan ekologis. Jakarta: HuMa.

. (2005a, April). Hukum progresif: Hukum yang membebaskan. Jurnal Hukum Progresif, l(1).

. (2005b, Oktober). Pendekatan holistik terhadap hukum. Jurnal Hukum Progresif, 1(2).

. (2006, April). Hukum progresif: Hukum yang membebaskan. Jurnal Hukum Progresif, 1(1), 23-24.

(2007, Oktober). Hukum progresif berdamai dengan alam. Jurnal Hukum Progresif, 3(2), 7.

. (2009). Pendidikan hukum sebagai pendidikan manusia. Yogyakarta: Genta Publishing. 
(2010). Mengajarkan keteraturan

menemukan ketidakteraturan. Pidato

mengakhiri jabatan sebagai Guru Besar Tetap pada Fakultas Hukum, UNDIP, Semarang.

Rahayu, E.W.P. (2005). Pranata hukum sebuah telaah sosiologis. Semarang: PT Suryandaru Utama.

Samekto, F.X.A. (2012). Ilmu hukum dalam perkembangan pemikiran menuju postmodernisme. Bandar Lampung: Indepth Publishing.

Sidharta. (2013). Hukum penalaran dan penalaran hukum. Yogyakarta: Gentha Publishing.

Susila, S. (2013). Sekularisme sebagai penjahat sekaligus pendusta agama. Forum Pengkajian Pitulasan Banyumanik Semarang.

Suteki. (2004, Agustus 4). Kebijakan tidak menegakkan hukum (Non enforcement of law), demi pemuliaan keadilan substansif. Pidato Pengukuhan. Semarang.

Wignjosoebroto, S. (2012). Hukum yang tak kunjung tegak: Apa yang salah dengan kerja penegakan hukum di negeri ini? Dalam Dialektika Pembaharuan Sistem Hukum Indonesia. Jakarta: Komisi Yudisial RI.

Yusriyadi. (2004). Polisi dan aspek penegak hukum secara sosiologis. Jurnal Hukum Progresif, 4(1), halaman. 